\title{
Syntheses and molecular structures of organolanthanoids
}

\author{
Qi Shen, Wenqi Chen, Yingtai Jin, Chengji Shan \\ Changchun Institute of Applied Chemistry, Academia Sinica, Changchun \\ Jilin, China
}

\begin{abstract}
This paper presented the main results obtained by our study on the syntheses and molecular structures of organolighterlanthanoide compounds in recent years. The synthetic methods for preparing cyclopentadienyllighterlanthanoide chlorides are described. New types of phenyl derivatives of neodymium such as $\mathrm{Li}(\mathrm{DME})_{3}\left(\mathrm{C}_{5} \mathrm{H}_{5}\right)_{3} \mathrm{NaC}_{6} \mathrm{H}_{5}, \mathrm{Nd}_{2}\left(\mathrm{C}_{6} \mathrm{H}_{6}\right)_{3}$ and $\mathrm{C}_{6} \mathrm{H}_{5} \mathrm{NdCl}$ were synthesized by the reaction of $\left(\mathrm{C}_{5} \mathrm{H}_{5}\right)_{2} \mathrm{NdCl} 2 \mathrm{LiCl}$ with $\mathrm{LiC}_{6} \mathrm{H}_{5}$ and metal vaporization technique respectively. Organoneodymium hydride and the polynuclear neodymium-aluminium bimetallic complexes $\left(\mathrm{Al}_{3} \mathrm{Nd}_{6}\left(\mu_{2}-\mathrm{Cl}\right)_{6}\left(\mu_{3}-\mathrm{Cl}\right)_{6}\left(\mu_{2}-\mathrm{Et}\right)_{9} \mathrm{Et} 5_{5}^{\mathrm{O}-\mathrm{i}-\mathrm{Pr})_{2}}\right.$ and $\left(\left(\mathrm{CF}_{3} \mathrm{COO}\right)_{3} \mathrm{NdAIH}\left(\mathrm{C}_{4} \mathrm{H}_{9}\right)_{2}\right)_{2}$ were isolated and their structures are discussed. The reaction of the reduced product of neodymium trichloride by lithium methylnaphthalene with cyclooctatetraere was investigated.
\end{abstract}

\section{INTRODUCTION}

Since 1954 Wilkinson and Birmingham prepared the first $\pi$-complexes of the lanthanoides, tricyclopentadienyl derivatives of lanthanoides (ref. 1), the studies on the syntheses of new organolanthanoide compounds have begun to attract wide attention. As a result of it, many of the compounds such as cyclopentadienyllanthanoide chlorides, cylooctatetraenyl complexes of the lanthanoides, alkyl or aryl compounds of the lanthanoides, organolanthanoide hydrides,' especially the neutral $\eta^{6}$-arene complex, $\left(\mathrm{Me}_{6} \mathrm{C}_{6}\right) \mathrm{Sm}\left(\mathrm{AlCl}_{4}\right) 3$ (ref. 2 ), $\eta^{2}$-acetylene complex, $\left(\mathrm{Me}_{5} \mathrm{C}_{5}\right)_{2} \mathrm{Yb}(\mathrm{MeC} \equiv \mathrm{CMe})$ (ref. 3) and $\eta^{2}$-olefine complex, $\left(\mathrm{Me}_{5} \mathrm{C}_{5}\right)_{2} \mathrm{Yb}\left(\boldsymbol{\eta}-\mathrm{C}_{2} \mathrm{H}_{4}\right) \mathrm{Pt}\left(\mathrm{PPh}_{3}\right)_{2}($ ref. 4$)$ have been synthesized and some of them were characterized by X-ray structure analysis.

It should be pointed out that most of the work published so far has been centered on the organometallic compounds of the heavier lanthanoide metals. Since the lighter lanthanoide metals are relatively abundant, the development of their chemistry is worthy of being noticed. We have put emphasis on the investigation of the syntheses and molecular structures of the organolighterlanthanoide compounds and have succeeded in isolating and characterizing a number of new compounds such as cyclopentadienyllighterlanthanoide chlorides, new types of phenyl derivatives of neodymium, organoneodymiumhydrides and the new polynuclear neodymium-aluminium bimetallic compounds. We also studied the reductive chemistry of lighter lanthanoides and the reaction of reduced product of neodymium trichloride and lithium naphthalene with cyclooctatetraene was described.

\section{CYCLOPENTADIENYLLIGHTERLANTHANOIDE CHLORIDES}

Cyclopentadienyllanthanoide chlorides are valuable synthetic precursors. The bicyclopentadienyllanthanoide chlorides from samarium to lutetium have been prepared by the transmetallation reaction of lanthanoide trichlorides with $\mathrm{NaC}_{5} \mathrm{H}_{5}$ in THF. They can also be prepared by the reaction of lanthanoide trichlorides and $\left(\mathrm{C}_{5} \mathrm{H}_{5}\right){ }_{3} \mathrm{Ln}$ (ref. 5 ). But all attempts to prepare the analogue of the lighter lanthanoides had failed before 1980. It suggests that the lanthanoides constriction may play a subtle role in the stability of the complexes. In 1980 It was found that the use of a bulky substituted cyclopentadienyl ligands such as $-\mathrm{C}_{5} \mathrm{Me}_{5}$ (ref. 6), $-\mathrm{C}_{5} \mathrm{H}_{4} \mathrm{SiMe}_{3}$ (ref. 7) and bridged dicyclopentadienyl ligand (ref. 8) allows the isolation of these important intermediates.

We have also investigated the syntheses of substituted cyclopentadienyllanthanoide chlorides and have isolated $\mathrm{Li}(\mathrm{THF})_{2}(\boldsymbol{\mu}-\mathrm{Cl})_{2} \mathrm{Ln}\left(\mathrm{C}_{5} \mathrm{Me}_{4} \mathrm{Et}\right)_{2} \mathrm{Ln}=\mathrm{Nd}, \mathrm{Gd}$ and $\mathrm{Li}(\mathrm{THF})_{2}(\mu-\mathrm{Cl})_{2} \mathrm{Gd}_{5}\left(\mathrm{C}_{5} \mathrm{Me}_{5}\right)_{2}$ ' $\mathrm{K}(\mathrm{THF})_{2}(\mathcal{H}-\mathrm{Cl})_{2} \mathrm{Nd}\left(\mathrm{C}_{5} \mathrm{Me}_{4} \mathrm{n}-\mathrm{Pr}\right)_{2}$ by using the metallation reaction of lanthanoide trichlorides and $\mathrm{Li}\left(\mathrm{C}_{5} \mathrm{Me}_{4} \mathrm{R}\right)(\mathrm{R}=\mathrm{Me}$, Et or $\mathrm{n}-\mathrm{Pr})$ or $\mathrm{K}\left(\mathrm{C}_{5} \mathrm{Me}_{4} \mathrm{n}-\mathrm{Pr}\right)($ ref. 9$)$. 
If $(\mathrm{pyH})_{2}\left(\mathrm{CeCl}_{6}\right)$ (py=pyridine) is used then only the complexes of $\mathrm{Ce}^{3+}$, $\left(\mathrm{C}_{5} \mathrm{Me}_{5}\right)_{2} \mathrm{CeClLICl}(\mathrm{py})_{2},\left(\mathrm{C}_{5} \mathrm{Me}_{5}\right) \mathrm{CeCl}_{2} \mathrm{LiCl}(\mathrm{py})_{2}$ or $\left(\mathrm{C}_{5} \mathrm{Me}_{5}\right)_{2} \mathrm{CeCl}$ are obtained depending on the reaction conditions used (ref. 10).

We found, however, even by using simple cyclopentadiene as ligand the derlvatives of cyclopentadienyllighterlanthanoide chlorides can also be synthesized with improved preparative conditions. When $\mathrm{NdCl}_{3} 2 \mathrm{THF}$, instead of anhydrous neodymium trichloride, reacted with $\mathrm{NaC}_{5} \mathrm{H}_{5}$ in a molar ratio of $1: 1$ or $1: 2$ in tetrahydrofuran, $\left(\eta^{5}-\mathrm{C}_{5} \mathrm{H}_{5}\right) \mathrm{NdCl}_{2} 3 \mathrm{THF}$ or $\left(\eta^{5}-\mathrm{C}_{5} \mathrm{H}_{5}\right){ }_{2}$ NdClTHF was prepared correspondingly. The preparation of $\left(\eta^{5}-\mathrm{C}_{5} \mathrm{H}_{5}\right) \mathrm{NdCl}_{2} 3 \mathrm{THF}$ was achieved by allowing neodymium trichloride to react with $\mathrm{NaC}_{5} \mathrm{H}_{5}$ in a molar ratio of $2: 1$.

Figure 1 shows the ligand arrangement of $\left(\eta^{5}-\mathrm{C}_{5} \mathrm{H}_{5}\right) \mathrm{NdCl}{ }_{2} 3 \mathrm{THF}$. The central atom neodymium is bonded to the five carbon atoms of cyclopentadiene and three oxygen atoms of the three tetrahydrofuran molecules to form a coordination polyhedron (ref. 11). The molecular structure is the same as that of $\left(\eta^{5}-\mathrm{C}_{5} \mathrm{H}_{5}\right) \mathrm{ErCl}_{2} 3 \mathrm{THF}$ (ref. 12).

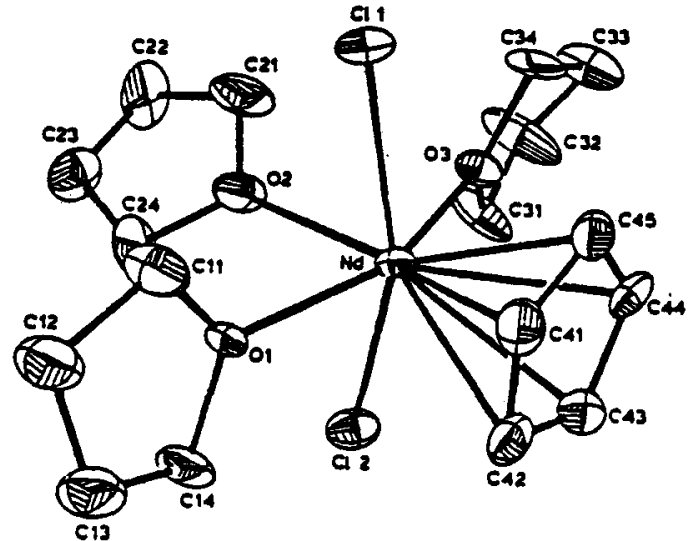

Fig. 1. Structure of $\left(\eta^{5}-\mathrm{C}_{5} \mathrm{H}_{5}\right) \mathrm{NaCl}_{2} 3 \mathrm{THF}$

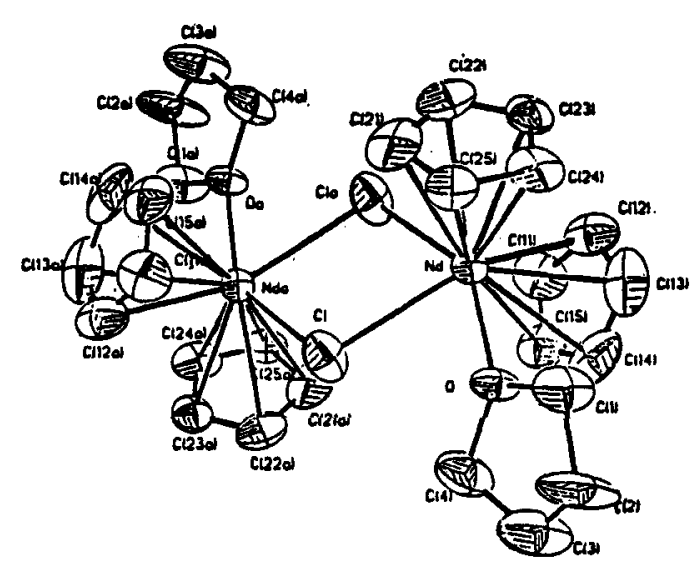

Fig. 2. Molecular structure of $\left(\left(\eta^{5}-\mathrm{C}_{5} \mathrm{H}_{5}\right)_{2} \mathrm{NdCITHF}\right)_{2}$

Figure 2 shows the molecular structure of $\left(\left(\eta^{5}-\mathrm{C}_{5} \mathrm{H}_{5}\right)_{2} \mathrm{NdClTHF}\right)_{2}$ to be a dimer in which the metal neodymium atoms are asymmetrically bridged by two chlorine atoms (ref. 13). It is different from the structure of $\left(\left(\eta^{5}-\mathrm{C}_{5} \mathrm{H}_{5}\right)_{2} \mathrm{ScCl}\right)_{2}$ in which the metal atoms are symmetrically bridged to two chlorine atoms (ref. 14). It can be attributed to the coordination of tetrahydrofuran. The coordinated tetrahydrofuran makes symmetric bridge change into asymmetric. The coordination number of neodymium atom is 9 .

We have also found the reaction of $\mathrm{LnCl}_{3} 2 \mathrm{LiCl}$ with only one equivalent of $\mathrm{NaC}_{5} \mathrm{H}_{5}$ allows the isolation of anionic cyclopentadienyllanthanoide dichloride ( $\left.\mathrm{Li}(\mathrm{THF})_{2}\right)_{2}(\mu-\mathrm{Cl})_{4}\left(\eta^{5}-\mathrm{C}_{5} \mathrm{H}_{5}\right) \mathrm{NdTHF}$ or ( $\left.\mathrm{Li}(\mathrm{THF})_{2}\right)_{2}(\mu-\mathrm{Cl})_{4}\left(\eta^{5}-\mathrm{C}_{5} \mathrm{H}_{5}\right)$ LaTHF in about $60 \%$ yield (ref. 15$)$.

$$
\mathrm{LnCl}_{3} 2 \mathrm{LiCl}+\mathrm{NaC}_{5} \mathrm{H}_{5} \longrightarrow\left(\mathrm{Li}(\mathrm{THF})_{2}\right)_{2}\left(\mu-\mathrm{CI}_{4}\right)_{4}\left(\eta^{5}-\mathrm{C}_{5} \mathrm{H}_{5}\right) \operatorname{LnTHF}(\mathrm{Ln}=\mathrm{La}, \mathrm{Nd})
$$

The two complexes crystallize in the orthorbombic space group Pna2 1 with $Z=4$. The molecular structure of $\left(\mathrm{Li}(\mathrm{THF})_{2}\right)_{2}(\mu-\mathrm{Cl})_{4}\left(\eta^{5}-\mathrm{C}_{5} \mathrm{H}_{5}\right) \mathrm{NdTHF}$ is shown in Fig. 3. The neodymium atom is bonded to one $\eta^{5}-\mathrm{C}_{5} \mathrm{H}_{5}$, to four bridged chlorine atoms and to one oxygen atom from $T H F$, each lithium cation bonded to two bridge chlorine atoms and two oxygen atoms of the two THF molecules to constitute a tetrahedron arrangement.

\section{CYCLOOCTATETRAENYL DERIVATIVES OF NEODYMIUM}

So far cyclooctatetraenyl compounds of the lanthanoide in the trivalent oxidation state were prepared by the reaction of lanthanolde trichlorides with $\mathrm{K}_{2} \mathrm{C}_{8} \mathrm{H}_{8}$ or cocondensation of lanthanum, cerium, neodymium or erbium metal atoms with cyclooctatetraene at $77 \mathrm{~K}$. The preceding reaction affords $\left(\mathrm{C}_{8} \mathrm{H}_{8} \mathrm{LnCl}(\mathrm{THF})_{2}\right)_{2}$ or $\mathrm{K}\left(\mathrm{Ln}\left(\mathrm{C}_{8} \mathrm{H}_{8}\right)_{2}\right)$ according to the reaction conditions used (ref. 16 ), while cocondensation yields $\mathrm{Ln}_{2}\left(\mathrm{C}_{8} \mathrm{H}_{8}\right)_{3}$ ( $\mathrm{ref} .17$ ). 


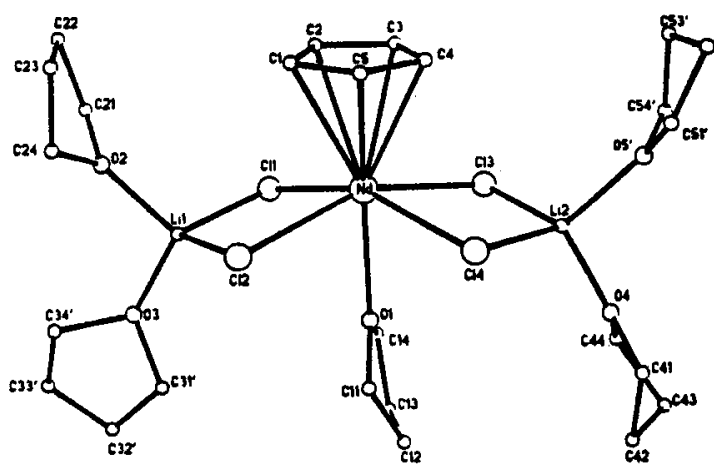

Fig. 3. Molecular structure of $\left(\mathrm{Li}(\mathrm{THF})_{2}\right)_{2}(\mu-\mathrm{Cl})_{4}\left(\eta^{5}-\mathrm{C}_{5} \mathrm{H}_{5}\right) \mathrm{NdTHF}$

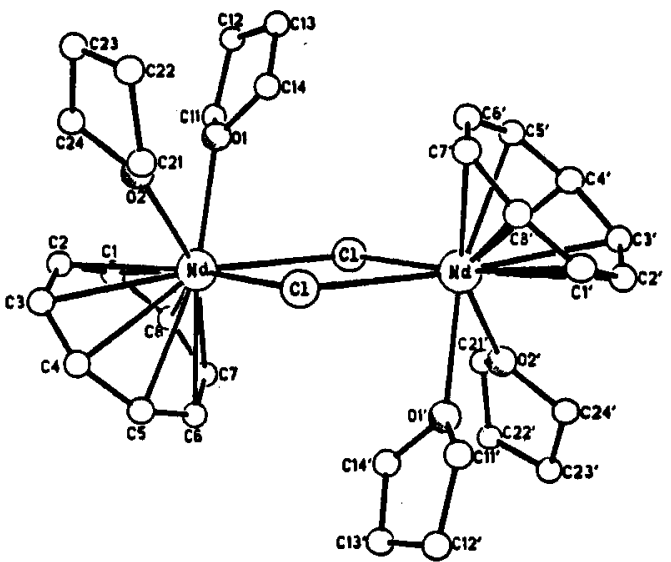

Fig. 4. Ortep plot of the molecular structure $\left(\left(\mathrm{C}_{8} \mathrm{H}_{8}\right) \mathrm{NdCl} 2 \mathrm{THF}\right)_{2}$

In our study on the solution syntheses of lanthanoide complexes in which a reduced oxidation state of the metal is involved, we found that a black product was precipitated when neodymium trichloride was reduced by 2 equiv of lithiummethylnaphthalene in THF. The black reduced product, which contains $0.8 \%$ lithium, $56.8 \%$ neodymium, $14.5 \%$ chlorine and ca. $28 \%$ of THF and methylnaphthalene, can react directly with cyclooctatetraene to give two complexes of $\left(\mathrm{C}_{8} \mathrm{H}_{8} \mathrm{NdCl2THF}\right)_{2}$ and $\left(\mathrm{Li}(\mathrm{THF})_{4} \mathrm{Nd}\left(\mathrm{C}_{8} \mathrm{H}_{8}\right)_{2} \mathrm{THF}\right)$. It is supported that the reaction of the reduced product and cyclooctatetraene gives $\mathrm{C}_{8} \mathrm{H}_{8} \mathrm{NdCl}$ and $\mathrm{Li}_{2} \mathrm{C}_{8} \mathrm{H}_{8}$ first and then the formed two complexes react further in situ to generate the new compound LiNd $\left(\mathrm{C}_{8} \mathrm{H}_{8}\right)_{2} 6 \mathrm{THF}$.

The structure of $\left(\mathrm{C}_{8} \mathrm{H}_{8} \mathrm{NdCl2THF}\right)_{2}$ is similar to that of $\left(\mathrm{C}_{8} \mathrm{H}_{8} \mathrm{CeC12THF}\right)_{2}$ (ref. 18). The two neodymium atoms are bridged asymmetrically by the two chlorine atoms and each neodymium atom is coordinated by one cyclooctatetraenyl ring and two THF molecules. The formal coordination number of neodymim atom is 9 (Fig. 4).

The molecular structure of $\mathrm{Li}(\mathrm{THF})_{4} \mathrm{Nd}\left(\mathrm{C}_{8} \mathrm{H}_{8}\right){ }_{2}$ 2THF consists of a discontact ion pair $\left(\mathrm{Nd}\left(\mathrm{C}_{8} \mathrm{H}_{8}\right)_{2}\right)^{-}$and $\left(\mathrm{K}(\mathrm{THF})_{4}\right)^{+}$. The anion consists of a central neodymium atom lying on the mirror plane which is symmetrically $\pi$-bonded to the two $\left(\mathrm{C}_{8} \mathrm{H}_{8}\right)^{2-}$ rings. The lithium cation is only coordinated by the four THF and the other two THF molecules fill in crystal lattice as free THF molecules (Fig. 5).

Thus the structure of $\mathrm{Li}(\mathrm{THF})_{4} \mathrm{Nd}\left(\mathrm{C}_{8} \mathrm{H}_{8}\right)_{2} 2 \mathrm{THF}$ is different from that of $\mathrm{K}$ (diglyme) $\left(\mathrm{Ce}\left(\mathrm{C}_{8} \mathrm{H}_{8}\right)_{2}\right)$, as published already, in which the molecular structure consists of a contact ion pair formed by $\left(\mathrm{Ce}\left(\mathrm{C}_{8} \mathrm{H}_{8}\right)_{2}\right)^{-}$anion and the diglyme coordinated potassium cation. The potassium ion also lies on the crystalographic mirror plane. Only one side of the potassium ion coordinated by the diglyme, the remaining side is symmetrically coordinated to $\left(\mathrm{C}_{8} \mathrm{H}_{8}\right)^{2-}$ ring (ref. 19).

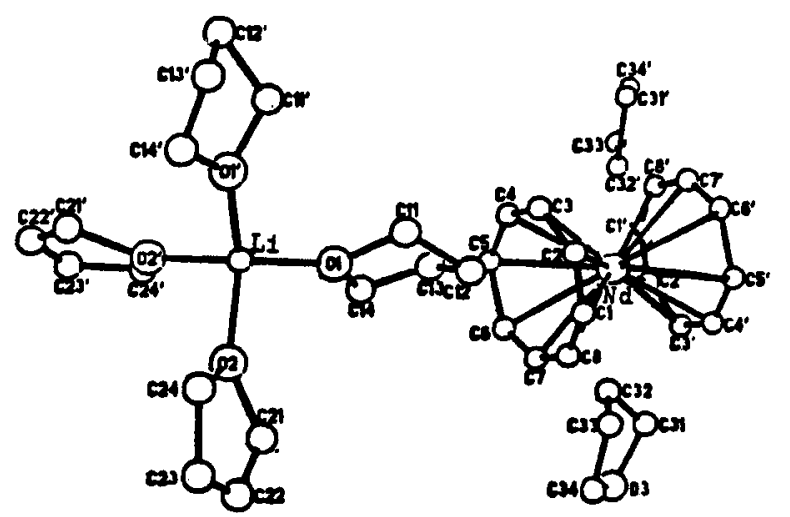

Fig. 5. The ortep drawing of $\mathrm{Li}(\mathrm{THF})_{4} \mathrm{Nd}\left(\mathrm{C}_{8} \mathrm{H}_{8}\right)_{2} 2 \mathrm{THF}$

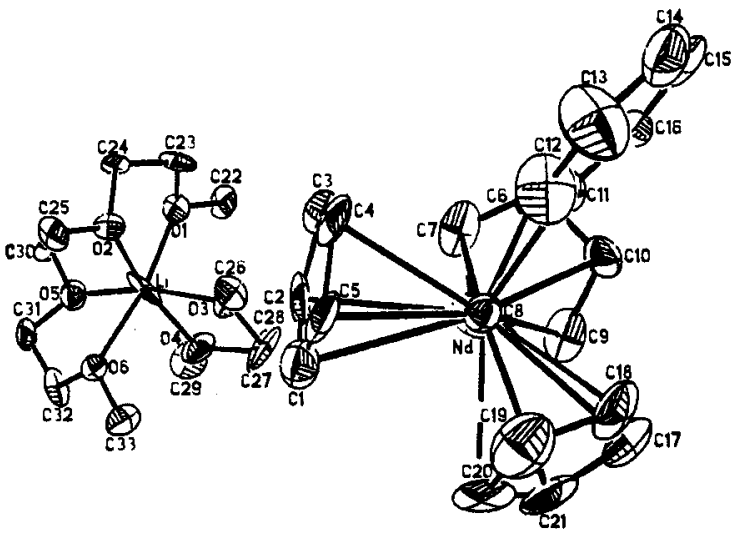

Fig. 6. The molecular structure of $\mathrm{Li}(\mathrm{DME})_{3}\left(\eta^{5}-\mathrm{C}_{5} \mathrm{H}_{5}\right) 3^{\mathrm{NdC}} 6 \mathrm{H}_{5}$ 


\section{NEW TYPES OF PHENYL DERIVATIVES OF NEODYMIUM}

The phenyl derivatives of lanthanides $\mathrm{Sc}\left(\mathrm{C}_{6} \mathrm{H}_{5}\right)_{3}, \mathrm{Y}\left(\mathrm{C}_{6} \mathrm{H}_{5}\right)_{3}$, LiLa $\left(\mathrm{C}_{6} \mathrm{H}_{5}\right)_{4}$ and $\operatorname{LiPr}\left(\mathrm{C}_{6} \mathrm{H}_{5}\right)_{4}$ were prepared by Hart et al (ref. 20). We also use the reaction of neodymium trichloride or gadolinium trichloride with 3 equiv of $\mathrm{LiC}_{6} \mathrm{H}_{5}$ to synthesize $\mathrm{Nd}\left(\mathrm{C}_{6} \mathrm{H}_{5}\right)_{3}, \mathrm{Gd}\left(\mathrm{C}_{6} \mathrm{H}_{5}\right)_{3}($ ref. 21).

The phenyl derivatives of lanthanides stabilized by cyclopentadienyl ligands were reported recently. But only the molecular structure of the complex $\left(\eta^{5}-\mathrm{C}_{5} \mathrm{Me}_{5}\right){ }_{2} \mathrm{SmC}_{6} \mathrm{H}_{5} \mathrm{THF}$ was determined in detail (ref. 22).

We have recently isolated a new type of anionic phenyl complex of neodyminm $\mathrm{Li}(\mathrm{DME})_{3}\left(\eta^{5}-\mathrm{C}_{5} \mathrm{H}_{5}\right)_{3} \mathrm{NdC}_{6} \mathrm{H}_{5}$ (DME=dimethoxy-ethane) by the reaction of $\mathrm{LiC}_{6} \mathrm{H}_{5}$ and $\left(\eta^{5}-\mathrm{C}_{5} \mathrm{H}_{5}\right){ }_{2} \mathrm{Nd}-$ $\mathrm{Cl} 2 \mathrm{LiCl}$, which was formed from $\mathrm{NdCl}_{3} 2 \mathrm{LiCl}$ and 2 equiv of $\mathrm{NaC}_{5} \mathrm{H}_{5}$ in one-pot synthesis. The complex crystallizes with six $\left(\left(\eta^{5}-\mathrm{C}_{5} \mathrm{H}_{5}\right) 3^{\mathrm{NdC}}{ }_{6} \mathrm{H}_{5}\right)^{-}$anions, six lithium cations, eighteen dimethoxy-ethane molecules in the unit cell. Each neodymium atom is coordinated to three $\eta^{5}$-bonded cyclopentadienyl ligands and one $\sigma$-bonded phenyl group in a distorted tetrahedral arrangement (Fig. 6).

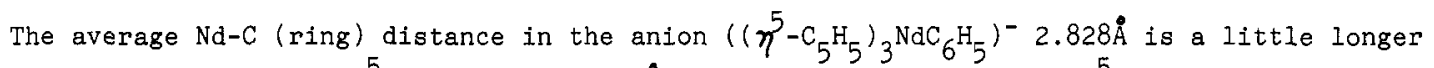
than the distance in $\left(\eta^{5}-\mathrm{C}_{5} \mathrm{H}_{5}\right)_{3} \mathrm{NdTHF} 2.79 \AA$ (ref. 23 ) and in $\mathrm{Li}$ (DME) $3\left(\eta^{5}-\mathrm{C}_{5} \mathrm{H}_{5}\right)_{3} \mathrm{Nd}(\mu-\mathrm{H}) \mathrm{Nd}-$ $\left(\eta^{5}-\mathrm{C}_{5} \mathrm{H}_{5}\right)_{3} 2.812 \AA$. The Nd-C (phenyl) $\sigma$-bond length in the anion is $2.605 \AA^{\circ}$. Because there is no such analogous phenyl derivative published in the literature, comparison of $2.605 \AA \mathrm{Nd}-\mathrm{C}$ distance can be made with other lanthanoide aryl compound if metal size and coordinative saturation are considered. $\left(\eta^{5}-\mathrm{C}_{5} \mathrm{Me}_{5}\right){ }_{2} \mathrm{SmC}_{6} \mathrm{H}_{5} \mathrm{THF}$ has $\mathrm{Sm}-\mathrm{C}$ (phenyl) distance of $2.511 \AA$. Since $\mathrm{Sm}^{3+}$ is approximately $0.03 \AA$ smaller than $\mathrm{Nd}^{3+}$, the $\mathrm{Nd}-\mathrm{C}$ distance is somewhat long compared to the Sm-C distance in $\left(\eta^{5}-C_{5} \mathrm{Me}_{5}\right)_{2} \mathrm{SmC}_{6} \mathrm{H}_{5} \mathrm{THF}$. This may be due to the increased steric congestion caused by three $\eta^{5}$-cyclopentadienyl ligands.

The metal vaporization technique has allowed to examine the reactivity of zerovalent lanthanoide metal and to synthesize the complexes which can not be prepared by normal reaction.

We investigated the reaction of neodymium metal vapor with benzene or chlorobenzene at $-196^{\circ} \mathrm{C}$. Cocondensation of neodymium metal vapor with benzene at $-196^{\circ} \mathrm{C}$ generated a black needle solid, which is insoluble in organic solvent, extremely air- and moisture-sensitive and pyrophoric in air. The chemical composition of the product was identified as $\mathrm{Nd}_{2}\left(\mathrm{C}_{6} \mathrm{H}_{6}\right)_{3}$ by chemical analysis (ref. 24). Cocondensation of neodymium metal vapor with chlorobenzene at $-196^{\circ} \mathrm{C}$ yielded a black matrix. The composition of the product was identified as $\mathrm{C}_{6} \mathrm{H}_{5} \mathrm{NdCl}$. The detailed molecular structures for both complexes need to be solved further (ref. 25).

\section{ORGANONEODYMIUM HYDRIDE}

There are several methods to prepare organolanthanoide hydrides in the literature and the different kinds of organoheavierlanthanoide hydrides were isolated and fully characterized. Until now no organolighterlanthanoide hydride was characterized by X-ray diffraction. When we studied the reductive chemistry of lighter lanthanoide elements, it was found that the organoneodymium hydride $\mathrm{L} 1(\mathrm{DME})_{3}\left(\eta^{5}-\mathrm{C}_{5} \mathrm{H}_{5}\right) \mathrm{Nd}(\mu-\mathrm{H}) \mathrm{Nd}\left(\eta^{5}-\mathrm{C}_{5} \mathrm{H}_{5}\right){ }_{3}$ was obtained from the reaction of $\left(\mathrm{C}_{5} \mathrm{H}_{5}\right)_{2} \mathrm{NdCl} 2 \mathrm{LiCl}$ and natrium methyl-naphthalene in molar ratio of $1: 1$ at $40^{\circ} \mathrm{C}$. The detailed reaction paths by which the complex is formed have not yet been clarified.

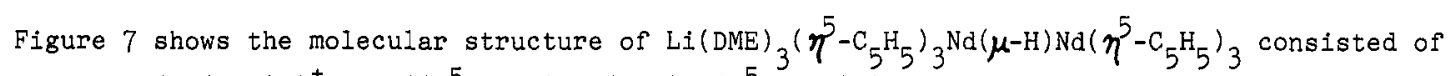
discrete $\left(\mathrm{Li}(\mathrm{DME})_{3}\right)^{+}$and $\left(\left(\eta^{5}-\mathrm{C}_{5} \mathrm{H}_{5}\right)_{3} \mathrm{Nd}(\mu-\mathrm{H}) \mathrm{Nd}\left(\eta^{5}-\mathrm{C}_{5} \mathrm{H}_{5}\right)_{3}\right)^{-}$. In the anion, each neodymium atom coordinated with three $\pi$-bonded cyclopentadienyl and a bridging hydrogen, which results in a coordination number 10 for neodymium atom. The average $\mathrm{Nd}-\mathrm{C}$ (ring) bond length is $2.812 \AA$, which is nearly equal to $2.79 \AA$ found in $\left(\eta^{5}-\mathrm{C}_{5} \mathrm{H}_{5}\right)$ NdTHF. The Nd-H bond length is calculated to be $2.190 \AA$, which is comparable to $\mathrm{Lu}-\mathrm{H}$ bond length $2.09 \AA$ in $\left(\left(\eta^{5}-\mathrm{C}_{5} \mathrm{H}_{5}\right) 3^{\mathrm{Lu}(\mu-\mathrm{H}) \mathrm{Lu}-}\right.$ $\left.\left(\eta^{5}-\mathrm{C}_{5} \mathrm{H}_{5}\right)_{3}\right)^{-}$if the difference of ionic radil between neodymium and lutetium is considered.

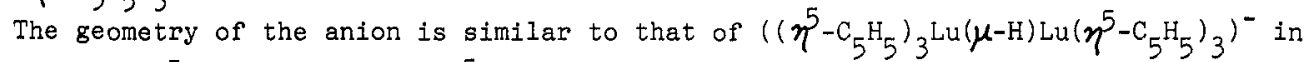
$\mathrm{Na}(\mathrm{THF})_{6}\left(\eta^{5}-\mathrm{C}_{5} \mathrm{H}_{5}\right)_{3} \mathrm{Lu}(\mu-\mathrm{H}) \mathrm{Lu}\left(\eta^{5}-\mathrm{C}_{5} \mathrm{H}_{5}\right)_{3}$ 2THF which is formed from the reaction of $\left(\mathrm{C}_{5} \mathrm{H}_{5}\right)_{3}$ Lu and NaH (ref. 26). This is the first fully-characterized organolighterlanthanoide hydride to our knowledge. 

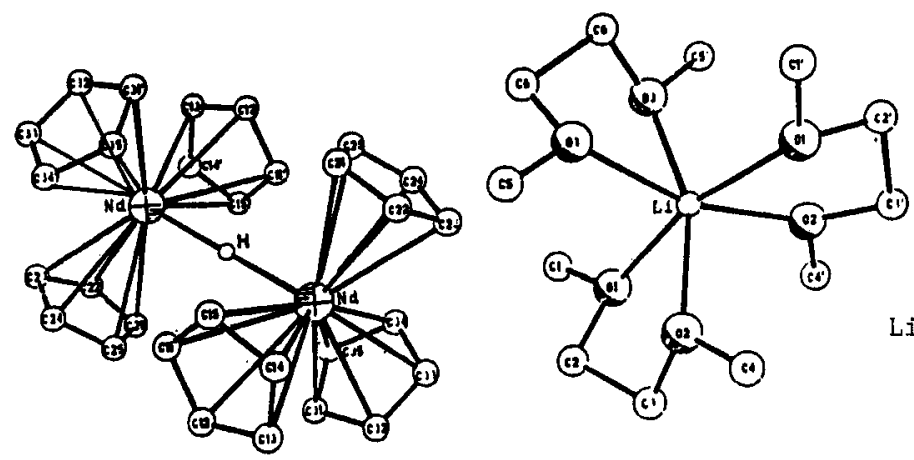

Fig. 7. The ortep drawing of $\mathrm{Li}(\mathrm{DME})_{3}\left(\eta^{5}-\mathrm{C}_{5} \mathrm{H}_{5}\right)_{3} \mathrm{Nd}(\mu-\mathrm{H}) \mathrm{Nd}\left(\eta^{5}-\mathrm{C}_{5} \mathrm{H}_{5}\right)_{3}$

We also found that $\mathrm{NdCl}_{2} 2 \mathrm{THF}$ reacted with 2 equiv of $\mathrm{NaC}_{5} \mathrm{H}_{5}$ in $\mathrm{THF}$, a analogous organoneodymium hydride $\mathrm{Na}(\mathrm{THF})_{6}\left(\eta^{5}-\mathrm{C}_{5} \mathrm{H}_{5}\right)_{3} \mathrm{Nd}(\mu-\mathrm{H}) \mathrm{Nd}\left(\eta^{5}-\mathrm{C}_{5} \mathrm{H}_{5}\right) 3^{2 \mathrm{THF}}$ was obtained in a way not clarified.

\section{NEODYMIUM-ALUMINIUM BIMETALLIC COMPLEXES}

Bridged homometallic or heterometallic transition metal-aluminium complexes are considered to be intermediates in Ziegler-Natta catalysis. Therefore it is meaningful to study the synthesis, molecular structure and reactivities of alkyl- or hydro-bridged lanthanoidealuminium bimetallic complexes for understanding the polymerization mechanism by rare rarth catalysts. Ballard first reported the syntheses of alkyl-bridged complexes of lanthanoide metals $\left(\eta^{5}-\mathrm{C}_{5} \mathrm{H}_{5}\right){ }_{2} \mathrm{M}(\mu-\mathrm{R})_{2} \mathrm{AlMe}_{2}(\mathrm{M}=\mathrm{Sc}, \mathrm{Y}, \mathrm{Gd}, \mathrm{Dy}, \mathrm{Ho}, \mathrm{Er}, \mathrm{Tm}$ or $\mathrm{Yb})$ and $\mathrm{X}$-ray structure data for $\left(\eta^{5}-\mathrm{C}_{5} \mathrm{H}_{5}\right)_{2} \mathrm{Yb}(\mu-\mathrm{Me})_{2} \mathrm{AlMe}_{2}$. These complexes are active for ethylene polymerization (ref. 27$)$.

We found that the reaction of $\left(\mathrm{CF}_{3} \mathrm{COO}\right)_{2} \mathrm{NdCl}$ with $\left(i-\mathrm{C}_{4} \mathrm{H}_{9}\right){ }_{2}^{\mathrm{AlH}}$ generates a neodymium-aluminium bimetallic complex $\left(\left(\mathrm{CF}_{3} \mathrm{COO}\right)_{3} \mathrm{NdAlH}\left(\mathrm{i}-\mathrm{C}_{4} \mathrm{H}_{9}\right)_{2} 2 \mathrm{THF}\right)_{2}$. The detailed reaction course remains obscure. The result of structure analysis shows that the complex is a dimer (Fig. 8). The central neodymium atom is nine coordinate being bonded to three $\mu_{3}-0$, which connect with aluminium, three $\mu_{2}-\mathrm{O}$ from three trifluoroacetate ligands, two THF molecules and one hydrogen atom. The position of the hydrogen atom in the molecule can not be exactly determined yet. Aluminium atom coordinates to $\mu_{3}-0, \mu_{2}-0$ with $A 1-0$ distance $1.813 \AA, 1.858 \AA$ respectively and to two terminal isobutyl groups with Al-C distance $1.944 \AA$.

Recently we have also succeeded in preparing another new type of neodymium-aluminium polynuclear bimetallic complex $\left(\mathrm{Al}_{3} \mathrm{Nd}_{6}\left(\mu_{2}-\mathrm{Cl}\right)_{6}\left(\mu_{3}-\mathrm{Cl}\right)_{6}\left(\mu_{2}-\mathrm{Et}\right)_{9} \mathrm{Et}{ }_{5}(\theta-i-\mathrm{Pr})\right)_{2}$ from the homogeneous ternary catalyst system $\mathrm{Nd}(\mathrm{O}-\mathrm{i}-\mathrm{Pr})_{3}-\mathrm{AlEt}_{3}-\mathrm{AlEt}_{2} \mathrm{Cl}$ (molar ratio=1:10:1.5) (ref. 28). The complex alone can initiate cis-1,4-polymerization of dienes. The results of butadiene polymerization are shown in Table. This is the first time for isolating active single crystals from a homogeneous catalytic system to our knowledge. X-ray diffraction analysis established the polynuclear complex to be a dimer as shown in Fig. 9.

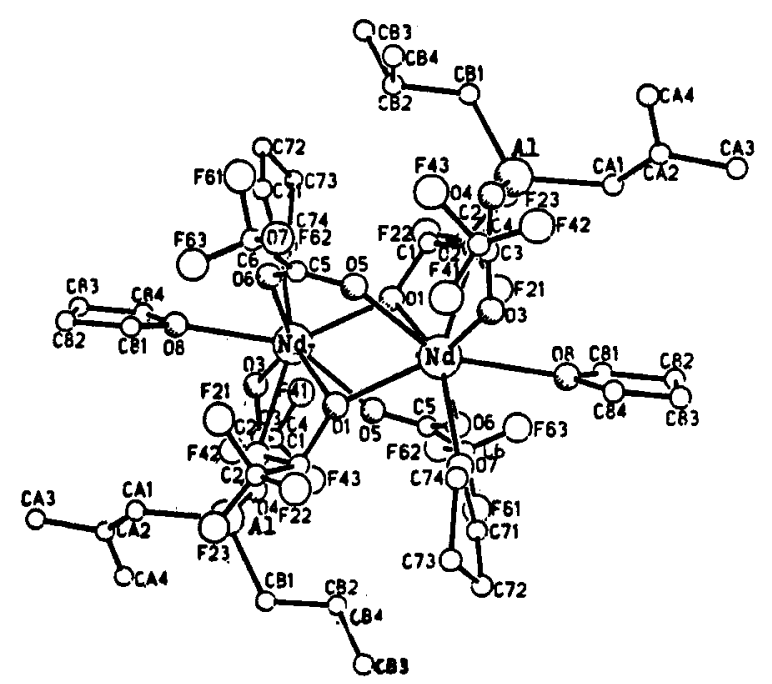

Fig. 8. Ortep drawing of $\left(\left(\mathrm{CF}_{3} \mathrm{COO}\right)_{3} \mathrm{NdAlH}\left(\mathrm{i}-\mathrm{C}_{4} \mathrm{H}_{9}\right)_{2}{ }^{2 \mathrm{THF}}\right)_{2}$

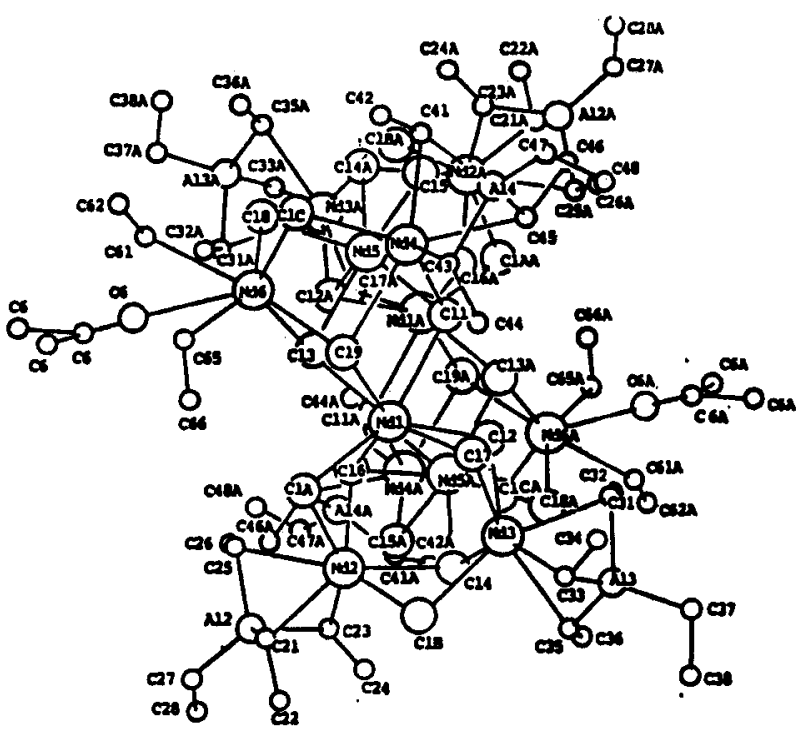

Fig. 9. Ortep drawing of $\left(\mathrm{Al}_{3} \mathrm{Nd}_{6}\left(\mu_{2}-\mathrm{Cl}\right)_{6}\left(\mu_{3}-\mathrm{Cl}\right)_{6}-\left(\mu_{2}-\mathrm{Et}\right)_{9} \mathrm{Et} t_{5}(\mathrm{O}-\mathrm{i}-\mathrm{Pr})\right)_{2}$ 
TABLE Results and polymerization

\begin{tabular}{|c|c|c|c|c|c|}
\hline \multirow[t]{2}{*}{ Catalyot } & \multirow{2}{*}{$\begin{array}{c}\text { Conversion } \\
\text { (x) }\end{array}$} & \multirow{2}{*}{$\begin{array}{l}(\eta) \\
(\mathrm{d} l / g)\end{array}$} & \multicolumn{3}{|c|}{ Microstructure $(\%)$} \\
\hline & & & $\operatorname{cis}-1,4$ & trans $-1,4$ & 1,2 \\
\hline $\begin{array}{l}\text { Precipitate } \\
\text { Single crystal } \\
\text { Ternary system }\end{array}$ & $\begin{array}{l}89.4 \\
89.5 \\
90.0\end{array}$ & $\begin{array}{l}8.29 \\
8.33 \\
4.35\end{array}$ & $\begin{array}{l}90.5 \\
91.1 \\
89.7\end{array}$ & $\begin{array}{l}8.6 \\
7.9 \\
8.9\end{array}$ & $\begin{array}{l}0.9 \\
1.0 \\
1.4\end{array}$ \\
\hline
\end{tabular}

Polymerization condition:

Butadiene $/ \mathrm{Nd}=5 \times 10^{4} \mathrm{~g} / \mathrm{mol} ., 50^{\circ} \mathrm{C}, 1 \mathrm{~h}, \mathrm{n}$-hexane as solvent

For ternary system: $\mathrm{AlEt}_{3} / \mathrm{Nd}\left(\right.$ molar ratio) $=10, \mathrm{AlEt}_{2} \mathrm{Cl} / \mathrm{Nd}$ (molar ratio) $=1.5$

All the neodymium atoms coordinate with seven ligands to constitute a distorted monocap-prism configuration. Neodymium atoms are connected by $\mu_{2}-\mathrm{Cl}$ and $\mu_{3}-\mathrm{Cl}$ into a molecular skeleton.

Neodymium and aluminium atoms are conbined togther by $\mu_{2}-\mathrm{Et}$. $\mathrm{Nd}_{1}$ and $\mathrm{Nd}_{5}$ are in the center of a cage constituted by seven bridged chlorine atoms. $\mathrm{Nd}_{3}$ and $\mathrm{Nd}_{4}$ are coordinated by four bridge chlorine atoms on one side and connected with aluminium atoms via three ethyl groups on the other side. This is the main part of the bimetallic complex. The coordination environment for $\mathrm{Nd}_{2}$ and $\mathrm{Nd}_{6}$ is a little different from that of $\mathrm{Nd}_{3}$ and $\mathrm{Nd}_{4}$. They both are linked to the molecular skeleton with four bridge chlorine atoms and coordinated to two k-thyl groups which are connected to aluminium and to oxygen of fered from isopropoxy with probabilities $(P)$ of 0.45 and 0.55 and or coordinated to two terminal ethyl groups and oxygen of isopropoxy with $P$ of 0.55 and 0.45 respectively. It means that when Nd2 coordinates to two $\mu$-ethyl groups Nd6 coordinates to two terminal ethyl groups or vice versa. A complex with so many bridged bonds had not been seen in rare-earth complex before.

\section{Acknowledgement}

We are pleased to thank our coworkers for their hard work, we also thank professor Jia-Zuan $\mathrm{Ni}$ and professor Zhi-Liu Feng for reading the manuscript and a number of useful comments. We are grateful to National Natural Science Foundation of China for financial support.

\section{REFERENCES}

1. G. Wilkinson, J.M. Birmingham, J. Am. Chem. Soc., 76, 6210-6210 (1954).

2. F.A. Cotton, W. Schwotzer, J.Am. Chem. Soc., 108, 4657-4658 (1986).

3. C.J. Burns, R.A. Andersen, J. Am. Chem. Soc., $\overline{109}, 941-942$ (1987).

4. C.J. Burns, R.A. Andersen, J. Am. Chem. Soc., $109,915-917$ (1987).

5. R.E. Maginn, S. Manastyrskyj, M. Dubeck, J. Am. Chem. Soc., 85, 672-676 (1963).

6. T.D. Tilley, R.A. Andersen, Inorg. Chem., 20, 3267-3270 (1981).

7. M.F. Lappert, A. Singh, J.L. Atwood, W.E. Hunter, J. Chem. Soc. Chem. Commun., 1190-1191 (1981).

8. J.N. John, M. Tsutsui, J. Coord. Chem., 10, 177-179 (1980).

9. Qi Shen, Heqin Ttan, Zeñgshun Sun, Rongxian Shi, Org. Chem., (China), 3, 241-244 (1985).

10. Peng Zhou, Heqin Tian, Qi Shen, Org. Chem., (China), 5, 385-388 (1985); Qi Shen, Peng Zhou, Kexue Tongbao, 30(4), 319-319 (1985).

11. Guangdi Yang, Yuguo Fan, Zhongsheng Jin, Yan Xing, Wenqi Chen, J. Organmet. Chem., 322, 56-63 (1987).

12. C.S. Day, V.W. Day, R.D. Evast, S.H. Volliner, Organometallics, 1, 998-1001 (1982).

13. Zhongsheng Jin, Yongsheng Liu, Wenqi Chen, Scientia Sinica, 1, 1-7 (1987).

14. J.L. Atwood, K.D. Smith, J. Chem. Soc., Dalton Trans., 2487-2490 (1973).

15. Yi L1, Xiaolong Xu, Guozhi Liu, Chinese J. Appl. Chem., accepted for publication.

16. K.O. Hodgson, F. Mares, D.F. Stark, A. Streitwieser, J. Am. Chem. Soc., 95, 8650-8658 (1973).

17. C.W. Dekock, S.R. Ely, T.E. Hopkins, M.A. Brault, Inorg. Chem., 17, 625-631 (197B).

18. K.O. Hodgson, K.N. Raymond, Inorg. Chem., 11, 171-175 (1972).

19. K.0. Hodgson, K.N. Raymond, Inorg. Chem., 11, 3030-3035 (1972).

20. F.A. Hart, M.S. Saran, J. Chem. Soc., Chem. Commun., 1614-1614 (1968).

21. Yumin Zhang, Wenqi Chen, Kexue Tongbao, 17, 1314-1315 (1986).

22. W.J. Evans, I. Bloom, W.E. Hunter, J.L. Atwood, Organometallics, 4, 112-119 (1985).

23. F. Bentolio, G. Bombieri, C. Bisi Castellani, W. John, R.D. Fischer, Inorg. Chim. Acta, $95(6)$, L7-L10 (1984).

24. Shuzhen Qi, Xueqin Gao, Shuhui Xiao, Wenqi Chen, Chinese J. Appl. Chem., 3, 63-66 (1986).

25. Shuzhen Qi, Xiaoxia Liu, Yumin Zhang, Wenqi Chen, Chinese J. Appl. Chem., 3 , 73-75 (1986).

26. H. Schumann, W. Genthe, E. Hahn, J. Organomet. Chem., 299, 67-84 (1986).

27. D.G.H. Ballard, A. Courtis, J. Holton, J. Mcmeeking, R. Pearce, J. Chem. Soc., Chem. Commun., 994 (1978).

28. Chengji Shan, Yonghua Lin, Jun Ouyang, Yuguo Fan, Guangdi Yang, Macromol. Chem., 188, 629-635 (1987). 